\title{
Le Congrès SFODF de Bruxelles. 25-28 mai 2006
}

$\mathrm{L}$ e congrès s'est déroulé autour du thème choisi par le président, Thierry De Coster : «Traitements orthodontiques précoces : les résultats justifient-ils les efforts consentis ?»

La plupart des orateurs français ont estimé que les avantages apportés par les traitements précoces étaient assez importants pour que l'augmentation de la durée globale du traitement soit justifiée.

Les conférenciers anglais et américains ont produit des statistiques impressionnantes, concernant en particulier les traitements des malocclusions de la classe II, division 1. Ils ont montré que, à la fin de la croissance, les deux stratégies (traitement en deux temps, précoce puis finition, ou tardif en un temps) donnaient des résultats très voisins, avec un léger avantage au traitement tardif. Les traitements en deux temps n'apportent aucun avantage mesurable en ce qui concerne les rapports squelettiques, malgré le port d'un activateur.

Cette opposition entre les stratégies n'est pas vraiment nouvelle. La nouveauté, pour laquelle ce congrès fera date, se situe sur le plan de l'épistémologie. Là un palier a été franchi.

Les conférenciers anglo-saxons n'ont pas abordé la question sous l'angle de la clinique, mais sous celui de la statistique (curieusement appelée «preuve par l'évidence» ou «l'évidence prouvée»). Cette approche ne consiste pas dans la production de séries de chiffres, mais dans l'adoption d'une rigoureuse méthode de travail : recrutement aléatoire (en franglais : «randomisé»), effectifs importants, échantillon témoin, etc. (pour plus de précisions voyez votre manuel de statistique médicale) C'est tout simplement, mais exactement et absolument, la méthode scientifique. Comme toute étude réellement scientifique, c'est incontestable, imparable mais enmuré : pas question d'extrapoler les résultats à d'autres types de malocclusions ou à d'autres techniques de traitement.

Les congressistes ont eu l'impression que deux approches intellectuelles s'affrontaient, d'un côté l'imagination, l'idéalisme, l'incoercible désir d'apporter un «plus», une pointe de romantisme et de passion, et de l'autre le poids glacé des chiffres trop objectifs pour être plaisants.

Le dernier jour a été consacré aux malocclusions de la classe III et aux unanimes louanges adressées à l'invention de J. Delaire (invention qu'on peut supposer être due plus au raisonnement et à l'imagination qu'à la statistique...)

Dans une autre salle étaient présentées les traditionnelles communications des membres de la S.F.O.D.F., plus cliniques et convaincantes que jamais.

Bref, un congrès passionnant, dirigé par son président avec maîtrise et bonhomie.

Julien PHILIPPE

29-05-06 


\section{EDITORIAL}

\section{The SFODF Convention in Brussels. May 25-28 2006}

T he convention was organized around the theme that President Thierry De Coster had chosen:

"Early orthodontic treatment: do the results justify the extra efforts required?"

Most of the French speakers judged that the advantages derived from early treatment are extensive enough to justify the increase they demand in over-all length of treatment.

The English and American speakers presented impressive statistics derived from treatment, especially of Class II div 1 malocclusions. They showed that at the end of the growth period, the two approaches, two-stage early and then finishing treatment, and one-stage delayed treatment produced nearly identical results, with delayed treatment having a slight edge. Two stage treatment strategies offered no measurable advantage in improving skeletal structures, despite the use of activators.

This confrontation between the two strategies is not really new. What is new is the epistemological approach that was, for the first time, taken at this convention. In that regard, the profession has moved forward to a new stage.

The Anglo-Saxon speakers did not approach the issues from a clinical standpoint but from a statistical base, called, somewhat curiously to the Gallic mind, "evidence-based". This way of thinking does not consist of the production of a series of numbers, but of the adoption of rigorous working methods using randomized subject selection in statistically valid numbers, control groups and the full range of inputs needed for reliability, all of which you can find in your manual on medical statistics. In short, their technique, to put it with rigorous simplicity, is to use the scientific method. Like all really valid scientific studies, these are incontestable, indisputable, but highly limited: there is no way their conclusions can be extrapolated to other types of malocclusions or to other treatment techniques.

Convention attendees were left with the impression that two intellectual approaches were clashing, on one side imagination, idealism, the irresistible desire to add one more "plus", a flash of romanticism and of passion and on the other side the ice-cold weight of numbers that were too objective to be pleasant.

The last day of the meeting was devoted to Class III malocclusions and to J. Delaire's invention, a contribution that one can conclude owed more to reasoning and to a sense of imagination than to statistics.

In another room S.F.O.D.F. members presented their time-honored communications that were more clinical and more convincing than ever.

In brief, the convention was passionately worthwhile and directed by its president with masterly skill and good nature.

Julien PHILIPPE 29-05-06 